\title{
Occurrence of Phytophthora species in watercourses and reservoirs in Poland and the threat to cultivated plants by this genera
}

\section{Występowanie Phytophthora w ciekach i zbiornikach wodnych w Polsce i zagrożenie upraw przez gatunki tego rodzaju}

\author{
Magdalena Ptaszek, Leszek B. Orlikowski*
}

\begin{abstract}
Summary
Phytophthora species are very dangerous plant pathogens, which can multiplicate in water because of zoospore formation and spread within it in particular regions, country or even continent. Additionally, increase of international plant trade has also resulted in the introduction of new Phytophthora species and their spread. Seventeen Phytophthora species were detected in Polish rivers, canals and water ponds with domination of $P$. plurivora and furthermore $P$. cambivora, $P$. cinnamomi, $P$. citrophthora, $P$. megasperma and $P$. lacustris. Phytophthora spp. were detected from water over the year with restriction during summer and winter using the rhododendron leaf baits. It was shown that Phytophthora isolates, regardless of water source and detection period were pathogenic to the tested plant species.
\end{abstract}

Key words: Phytophthora; water sources; occurrence; harmfulness

\section{Streszczenie}

Gatunki Phytophthora są groźnymi patogenami roślin, które dzięki zarodnikom pływkowym mogą rozwijać się w wodzie i rozprzestrzeniać się z nią w określonym regionie, kraju, a nawet na kontynencie. Wzrastający, międzynarodowy obrót materiałem roślinnym również powoduje zawlekanie nowych gatunków Phytophthora i powiększanie zasięgu ich występowania. W Polsce w ciekach i zbiornikach wodnych stwierdzono występowanie 17 gatunków tego rodzaju z dominacją $P$. plurivora, a następnie P. cambivora, P. cinnamomi, P. citrophthora, P. megasperma, P. lacustris. Stosując do detekcji patogenów liście pułapkowe różanecznika, Phytophthora spp. wykrywano w wodzie przez cały rok, ze znacznym ograniczeniem ich liczebności latem i zimą. Wykazano, że izolaty Phytophthora spp., niezależnie od miejsca i okresu detekcji, były patogeniczne dla testowanych gatunków roślin.

Słowa kluczowe: Phytophthora; źródła wody; występowanie; szkodliwość

Instytut Ogrodnictwa

Konstytucji 3 Maja 1/3, 96-100 Skierniewice

*corresponding author: leszek.orlikowski@inhort.pl 


\section{Wstęp / Introduction}

Heraklit z Efezu (540-480 p.n.e.) twierdził, iż nigdy nie można wejść do tej samej wody z uwagi na jej ciągłą zmienność. Problem ten dotyczy także rzek, strumieni i kanałów przepływających przez lasy, pola, tereny ogrodnicze, a także miasta i wsie, których skład gatunkowy mikroorganizmów ciągle zmienia się. Hong i Moorman (2005) w różnych źródłach wody zidentyfikowali 70 gatunków grzybów i organizmów grzybopodobnych, 8 gatunków bakterii, 10 wirusów i 13 gatunków pasożytniczych nicieni. Z kolei Thompson i Allen (1974) stwierdzili w wodzie 50 rodzajów grzybów i organizmów grzybopodobnych, a wśród nich około 1/4 patogenów roślin. Analizując skład mikroorganizmów w ciekach wodnych Miligroom i Peever (2003) uważają, że woda jest najbardziej dostępnym i najszybszym źródłem rozprzestrzeniania czynników chorobotwórczych w określonym regionie, kraju, a nawet na kontynencie. Baker i Matkin (1978) podają, że organizmy tworzace zoosporangia i zoospory, w tym gatunki Phytophthora i Pythium, są najczęściej występującymi w wodzie patogenami roślin. W środowisku wodnym, zoospory uwalniające się z zarodni pływkowych rozprzestrzeniają się w połączonym systemie rzek i zbiorników wodnych na znaczne odległości, opanowując w czasie podlewania czy lokalnych powodzi nowe rośliny żywicielskie. O zagrożeniu upraw przez omawiane patogeny świadczy nazwa rodzajowa - Phytophthora czyli czynnik destrukcyjny roślin. W piśmiennictwie gatunki tego rodzaju uważane są za groźne lub bardzo groźne patogeny roślin (Erwin i Ribeiro 1996).

\section{Występowanie Phytophthora spp. w wodzie}

Na rolę wody jako źródła patogenów zwrócono uwagę podczas intensyfikacji upraw, głównie ogrodniczych, gdy zaczęto systematycznie stosować ją do podlewania i nawożenia roślin, czego następstwem były często znaczne straty powodowane występowaniem symptomów zgnilizny podstawy pędu i korzeni (Thompson i Allen 1974). Pierwsze dane na temat występowania Phytophthora spp. w wodzie opublikowali Bewley i Buddin (1921) stwierdzając $P$. cryptogea w zbiorniku, z którego czerpano wodę do nawadniania upraw szklarniowych. 53 lata później Thompson i Allen (1974) izolowali z wody P. citrophthora, $P$. parasitica (= P. nicotianae var. nicotianae) i niezidentyfikowane izolaty tego rodzaju. $Z$ kolei Themann i wsp. (2002) w szkółce $\mathrm{z}$ zamkniętym obiegiem wody zidentyfikowali 12 gatunków tego rodzaju z dominacją $P$. gonapodyides, $P$. cryptogea, $P$. drechsleri i $P$. citricola. W wodzie używanej do podlewania Bush i wsp. (2003) określili ponadto P. megasperma, P. nicotianae var. nicotianae i $P$. palmivora.

W Polsce pierwsze badania nad rolą wody w rozprzestrzenianiu Phytophthora rozpoczęto w pierwszych latach 21. wieku i kontynuowano je do 2013 roku (Orlikowski i wsp. 2010, 2011a, b, 2012a, b). Efektem monitoringu rzek, kanałów i zbiorników wodnych było wykrycie 17 gatunków tego rodzaju. Autorzy stwierdzili występowanie Phytophthora spp. w wodzie niezależnie od lokalizacji zbiorników (tab. 1). W zbiornikach wodnych na terenie 4 gospodarstw szklarniowych zidentyfikowali 5 gatunków z dominacją $P$. cryptogea i $P$. plurivora, w 6 szkółkach 6 gatunków tego rodzaju (tab. 1), w tym głównie $P$. plurivora, $P$. cambivora i $P$. cinnamomi (Orlikowski i wsp. 2012a).

Tabela 1. Liczba zbiorników wodnych (n), w których stwierdzono występowanie gatunków Phytophthora (Orlikowski i wsp. 2012a)

Table 1. Number of water reservoirs (n) with the occurrence of Phytophthora species (Orlikowski et al. 2012a)

\begin{tabular}{l|c|c}
\hline $\begin{array}{l}\text { Gatunki Phytophthora } \\
\text { Phytophthora species }\end{array}$ & $\begin{array}{c}\text { Zbiorniki } \\
\text { szklarniowe } \\
\text { Greenhouse } \\
\text { reservoirs } \\
(\mathrm{n}=4)\end{array}$ & $\begin{array}{c}\text { Zbiorniki } \\
\text { w szkółkach } \\
\text { Nursery } \\
\text { reservoirs } \\
(\mathrm{n}=6)\end{array}$ \\
\hline P. cambivora & - & 4 \\
\hline P. cinnamomi & - & 4 \\
\hline P. citrophthora & 1 & 3 \\
\hline P. cryptogea & 2 & 3 \\
\hline P. lacustris & 1 & 2 \\
\hline P. plurivora & 3 & 6 \\
\hline P. tropicalis & 1 & - \\
\hline
\end{tabular}

W amerykańskich ciekach wodnych Hong i Moorman (2005) stwierdzili 17 gatunków Phytophthora. Wyniki swoich badań autorzy podsumowali wnioskiem, że zakażona woda jest głównym, jeśli nie jedynym, źródłem inokulum gatunków Phytophthora w szkółkach, sadach owocowych i warzywnikach, co jest dowodem na to, że gatunki Phytophthora mogą stanowić bardzo duże zagrożenie upraw ogrodniczych, nie tylko w USA, ale również i w Polsce.

\section{Źródla gatunków Phytophthora}

Już w 1961 roku Kozłowska i wsp. wiedzieli o występowaniu Phytophthora spp. jako zagrożeniu w uprawach leśnych. Badania Orlikowskiego i Oszako (2009) wykazały występowanie zarówno w lasach, jak i w szkółkach leśnych 9 gatunków tego rodzaju $\mathrm{z}$ dominacją $P$. citricola (obecnie $P$. plurivora), $P$. cactorum, $P$. cinnamomi i $P$. citrophthora. Z kolei Hansen i Delatour (1999) stwierdzili w rzekach przepływających przez lasy dębowe we Francji, 4 gatunki tego rodzaju $\mathrm{z}$ dominacją $P$. citricola oraz kilkanaście niezidentyfikowanych izolatów. Nechwatal i Mendgen (2006) z korzeni wierzb rosnących nad jeziorem Bodeńskim wyizolowali nowy gatunek określony jako taxon Salixsoil, który następnie oznaczono jako $P$. lacustris (Nechwatal i wsp. 2013). Występowanie P. gonapodyides i $P$. lacustris $\mathrm{w} 2$ rzekach $\mathrm{i} \mathrm{w}$ jeziorze na terenie południowo-zachodniej Ukrainy stwierdzili Matsiakh i wsp. (2012). Intensywne, wiosenne i letnie opady, wylewy rzek oraz wykorzystywanie wody z cieków wodnych do podlewania szkółek powodują szybkie rozprzestrzenianie się Phytophthora spp. i pojawianie się objawów zgnilizny podstawy pędów i korzeni na roślinach.

Istotną rolę $\mathrm{w}$ przeżywaniu omawianej grupy patogenów pełnią rośliny dziko rosnące i chwasty. Orlikowski i Ptaszek (2009) wykazali, że cykoria podróżnik, hyzop lekarski i rumian szlachetny są żywicielami P. cryptogea. 
W uprawach polowych gatunek ten, bytując w glebie, rozprzestrzeniany jest w czasie orki i zabiegów pielęgnacyjnych, a w warunkach naturalnych przenoszony przez owady oraz spłukiwany $\mathrm{z}$ wodą opadową do lokalnych strumieni lub rzek. Jest bardzo prawdopodobne, że wiele gatunków chwastów stanowi źródło energii dla innych gatunków tego rodzaju.

$\mathrm{W}$ minionym 25-leciu istotny wpływ na rozprzestrzenianie patogenów, w tym Phytophthora spp., miał międzynarodowy obrót materiałem roślinnym (Oszako i wsp. 2007; Brasier 2008). Na siewkach, sadzonkach i starszych roślinach zawleczono do kraju co najmniej kilkanaście najgroźniejszych gatunków tego rodzaju. Orlikowski i wsp. (1995) na roślinach wrzosowatych i iglastych, produkowanych na bazie importowanego materiału, po raz pierwszy w kraju stwierdzili występowanie $P$. cinnamomi i $P$. citricola ( $=$ P. plurivora). W następnych latach w szkółkach i w uprawach pod osłonami pojawiły się m.in.: P. cactorum, P. cambivora, $P$. citrophthora, $P$. cryptogea, $P$. nicotianae var. nicotianae, $P$. megasperma, P. plurivora, $P$. ramorum (Orlikowski i wsp. 2012a).

\section{Woda jako źródło rozprzestrzeniania patogenów w kraju i na kontynencie}

W 1999 roku Gibbs i wsp. (1999) zanotowali masowe zamieranie olszy nad brzegami brytyjskich rzek. Podobne doniesienia przekazali Streito i wsp. (2002) we Francji. W następnych kilku latach ukazały się prace informujące o często masowym zamieraniu olszy w lasach i nad brzegami rzek w Niemczech (Jung i Blaschke 2004) oraz w Polsce (Orlikowski i wsp. 2003). W następnym roku Cech (2004) potwierdził zamieranie olszy w Europie, od Grecji aż do krajów skandynawskich. Badania wykazały, że przyczyną choroby był $P$. alni (z 3 podgatunkami), który powoduje objawy zgnilizny podstawy pnia i korzeni drzew, co wiąże się z silnym zahamowaniem ich wzrostu, przejaśnieniem liści i często bardzo obfitym tworzeniem szyszek. Końcowym etapem rozwoju choroby jest zamieranie drzew. Opadające do wody liście lub uszkodzone wierzchołki pędów, a także resztki innych roślin są źródłem energii dla patogena i miejscem, obok porażonych drzew, ich rozmnażania. Zarodniki pływkowe uwalniające się z zarodni pływkowych, formujących się na skoloni- zowanych tkankach roślin, bardzo szybko rozprzestrzeniane są $\mathrm{z}$ wodą. Źródłem patogena mogą być także porażone siewki olszy i zakażona gleba w szkółce (Oszako i Orlikowski 2005).

Pod koniec 20. wieku w Kalifornii (USA) pojawiła się choroba określona jako nagłe zamieranie dębów, a powodowana przez P. ramorum (Rizzo i wsp. 2002; Murphy i Rizzo 2003). W ciągu kilkunastu lat patogen rozprzestrzenił się do stanu Washington, a następnie do Kanady. Wykazano, że w czasie dżdżystej i wietrznej pogody zarodnie pływkowe patogena tworzące się na porażonych liściach, porywane są przez wiatr i przenoszone często kilkadziesiąt-kilkaset metrów od miejsca wystąpienia choroby (Orlikowski i Szkuta 2005; Orlikowski i Wiejacha 2005; Oszako i wsp. 2007). W ten sposób stale pojawiają się nowe ogniska choroby. Patogena stwierdzono również w strumieniach przepływających przez porażone lasy (Orlikowski i Szkuta 2005).

\section{Detekcja Phytophthora spp. w wodzie}

Przez co najmniej półwiecze do izolacji gatunków Phytophthora stosowano pułapki roślinne wykorzystując: siewki, sadzonki, liście, części pędów i owoców (Erwin i Ribeiro 1996). Zaletą tej metody jest dostępność materiału roślinnego w okresie wegetacji, a nawet przez cały rok i bardzo niski koszt testowania. Efektywność detekcji patogenów z zastosowaniem pułapek jest uzależniona od stopnia zdrewnienia tkanek, okresu wykrywania i gatunku Phytophthora. Themann i wsp. (2002) w badaniach nad skażeniem wody przez Phytophthora spp. w zamkniętym obiegu w szkółce, do detekcji patogenów zastosowali test Elisa, filtrowanie oraz pułapki z liści różanecznika. Wykorzystując blaszki liściowe tej rośliny autorzy wyizolowali największą liczbę gatunków stwierdzając, że jest to najskuteczniejsza metoda detekcji.

W badaniach własnych Orlikowski i wsp. (2011b) stosowali jako pułapki liście dębu, olszy i różanecznika, które każdorazowo pobierano $\mathrm{z}$ wierzchołków pędów. Używano je od maja do września do wykrywania Phytophthora spp. z 2 rzek, przepływających przez tereny rolnicze i leśne oraz ze stawu usytuowanego w pobliżu

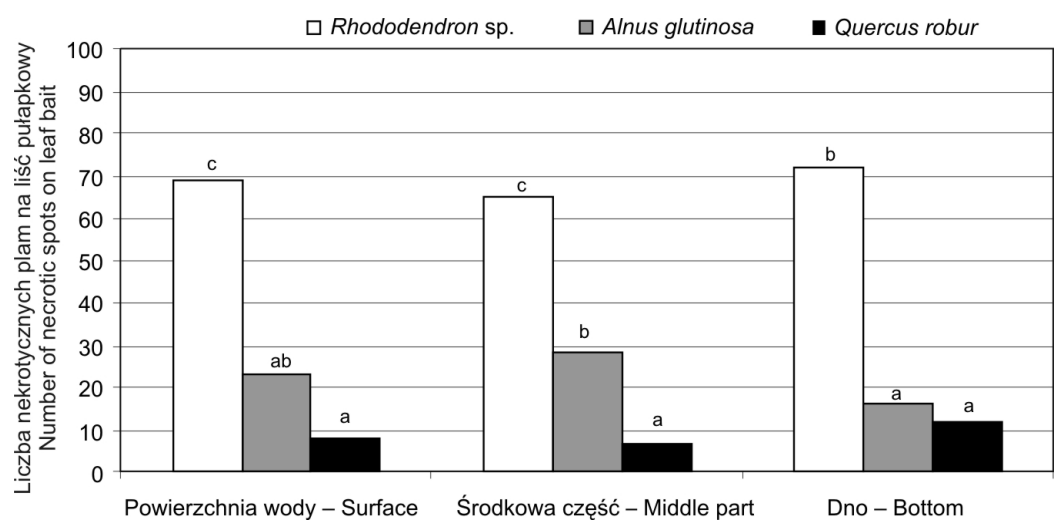

Średnie w kolumnach oznaczone tą samą literą, nie różnią się istotnie $(5 \%)$ według testu Duncana Means in columns followed by the same letter, do not differ according to Duncan's multiple range test

Rys. 1. Częstotliwość izolacji Phytophthora spp. w zależności od umiejscowienia pułapek w wodzie (Orlikowski i wsp. 2011b)

Fig. 1. Frequency of Phytophthora spp. isolation in relation to bait location in water (Orlikowski et al. 2011b) 


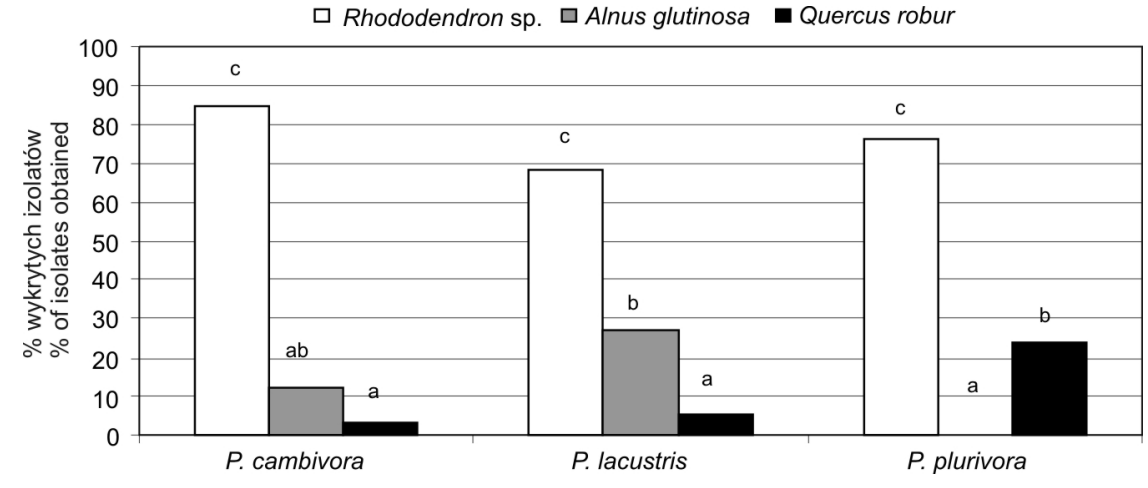

Średnie w kolumnach oznaczone tą samą literą, nie różnią się istotnie $(5 \%)$ według testu Duncana Means in columns followed by the same letter, do not differ according to Duncan's multiple range test

Rys. 2. Częstotliwość detekcji 3 gatunków Phytophthora w zależności od rośliny pułapkowej

Fig. 2. Frequency of 3 Phytophthora species detection in relation to plant bait

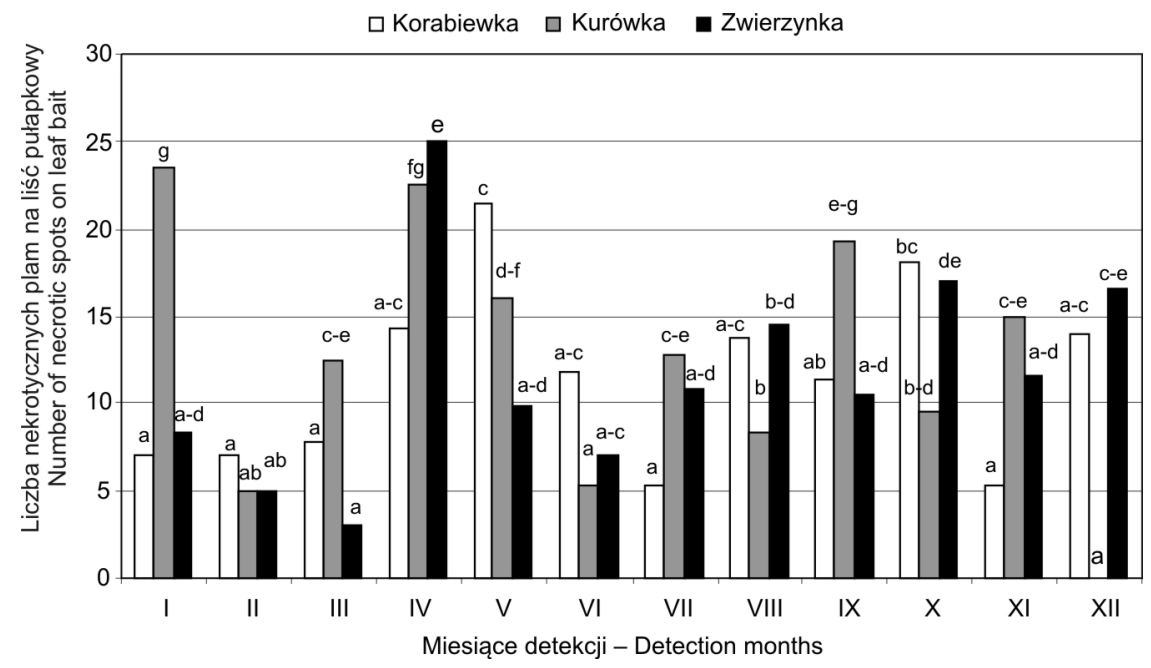

Średnie w kolumnach oznaczone tą samą literą, nie różnią się istotnie $(5 \%)$ według testu Duncana Means in columns followed by the same letter, do not differ according to Duncan's multiple range test

Rys. 3. Częstotliwość występowania Phytophthora spp. w 3 rzekach w zależności od terminu detekcji

Fig. 3. Frequency of Phytophthora spp. occurrence in 3 rivers in relations to detection months

szkółki leśnej. Pułapki umieszczano na powierzchni lustra wody oraz w środkowej i dolnej jego części (rys. 1). Miarą ich przydatności była liczba nekrotycznych plam na powierzchni blaszek liściowych, a także liczba wykrywanych izolatów gatunków $P$. cambivora, $P$. lacustris i P. plurivora (dawniej P. citricola) (rys. 2). Spośród testowanych pułapek, liście różanecznika dały możliwość zarówno ilościowego, jak i jakościowego określenia skażenia wody przez Phytophthora spp. Niezależnie od umiejscowienia pułapek w lustrze wody, okresu detekcji oraz gatunku Phytophthora, różanecznik okazał się najlepszą rośliną pułapkową (rys. 1, 2). Dodatkową zaletą różanecznika jest jego dostępność przez cały rok oraz duża trwałość w wodzie niezależnie od jej źródła i temperatury. Blaszki liściowe zachowują swoją świeżość przez co najmniej 7 dni i nie gniją jak inne pułapki. Wskazują na to wyniki detekcji Phytophthora prowadzonej przez cały rok w 3 rzekach (rys. 3). Niezależnie od pory roku, każdorazowo wykrywano omawianą grupę patogenów stosując liście różanecznika (rys. 3).

\section{Wpływ źródła wody i okresu detekcji na sklad gatunkowy Phytophthora spp.}

Znaczący wpływ na występowanie rodzaju Phytophthora i jego skład gatunkowy mają: źródło wody, usytuowanie stawów lub zbiorników $\mathrm{z}$ uwzględnieniem rodzaju i intensywności upraw, nawożenia i stosowanej ochrony oraz pory roku. W przeprowadzonych badaniach uwzględniono 4 rzeki, z których 2 przepływają w znacznej części przez lasy, a pozostałe przez tereny rolnicze. $Z$ kolei zbiornik wodny usytuowany jest obok szkółki leśnej i podczas niedoboru wody wykorzystuje się wodę z pobliskiej rzeki. Detekcję Phytophthora spp. prowadzono przez 11 miesięcy, poza lutym, stosując pułapki z liści różanecznika odmiany Nova Zembla. Dla każdego miesiąca detekcji określano liczebność występowania i skład gatunkowy tego rodzaju. Stwierdzono występowanie 5 gatunków Phytophthora, przy czym w każdym ze źródeł wody występował $P$. plurivora (tab. 2). Gatunek ten stwierdzano przez cały okres badań. W rzekach przepływających przez lasy (Korabiewka, Zwierzynka) obok P. plurivora, stwierdzono również $P$. citrophthora, $P$. lacustris i $P$. mega- 
Tabela 2. Współzależność pomiędzy źródłem wody, okresem detekcji a wykrywaniem gatunków Phytophthora (Orlikowski i wsp. 2012b)

Table 2. Relationship between water source, isolation period and detection of Phytophthora species (Orlikowski et al. 2012b)

\begin{tabular}{|c|c|c|c|c|c|}
\hline \multirow{2}{*}{$\begin{array}{l}\text { Miesiące detekcji } \\
\text { Isolation months }\end{array}$} & \multicolumn{4}{|c|}{ Rzeki-Rivers } & \multirow{2}{*}{$\begin{array}{c}\text { Zbiornik } \\
\text { Water reservoir }\end{array}$} \\
\hline & Korabiewka & Rawka & Skierniewka & Zwierzynka & \\
\hline I & P.plu & P.plu & - & - & - \\
\hline III & P.plu & P.plu & P.plu & - & P.plu \\
\hline IV & P.plu, P. ctph & P. plu & P.plu, P. ctph & P.plu & P.plu,P.ctph \\
\hline $\mathrm{V}$ & P.plu & P. plu & P.plu & P.plu, P. meg & P. plu, P. lac \\
\hline VI & P.plu, P. ctph & P.plu, P. cam & P.plu, P. ctph & P.plu, P. meg & P.plu, P. lac \\
\hline VII & P. plu & P.plu, P. cam & P.plu, P. cam & P.plu, P. meg & P.plu, P. lac \\
\hline VIII & P.plu & P.plu, P.cam & - & - & P. plu, P. lac \\
\hline IX & P. plu & P.plu, P.cam & P.plu, P.cam & - & P.plu \\
\hline$X$ & P. plu & P. plu & P.plu, P. meg & $\begin{array}{c}\text { P.plu, P. meg, } \\
\text { P.lac }\end{array}$ & P.plu, P. meg \\
\hline XI & P.plu & P.plu, P. meg & P. meg & P. lac & P.plu, P. meg \\
\hline XII & P. plu & - & - & P. lac & $P . p l u$ \\
\hline
\end{tabular}

P. cam-P. cambivora, P. ctph-P. citrophthora, P. lac-P. lacustris, P. meg-P. megasperma, P. plu-P. plurivora

sperma (tab. 2). W dwóch innych rzekach (Rawka i Skierniewka) dominował gatunek $P$. plurivora i $P$. cambivora, a także wykrywano $P$. citrophthora i $P$. megasperma. Nie stwierdzono natomiast $P$. lacustris. Najmniej gatunków Phytophthora zanotowano w rzece Korabiewice. W zbiorniku wodnym obok najliczniej notowanego gatunku $P$. plurivora, a następnie $P$. lacustris, stwierdzono P. citrophthora i $P$. megasperma (tab. 2). Najczęściej wykrywano wymienione gatunki w kwietniu, maju, czerwcu i lipcu, a następnie w październiku i listopadzie. Obok niskiej temperatury niewątpliwy wpływ na skład gatunkowy mogło mieć zanieczyszczenie wody przez pozostałości nawozów i środków ochrony roślin (sierpień i częściowo wrzesień). Analiza częstotliwości detekcji Phytophthora spp. w ciekach i zbiorniku wykazała duże jej zróżnicowanie od kwietnia do listopada, a w miesiącach zimowych brak występowania przedstawicieli tego rodzaju lub ich niższą liczebność (Orlikowski i wsp. 2012b).

\section{Szkodliwość gatunków Phytophthora z wody dla roślin}

Latem 2005 roku na żywotnikach uprawianych w szkółce pojemnikowej stwierdzono objawy brązowienia i stopniowego zamierania wierzchołków pędów. Z porażo- nych tkanek wyizolowano $P$. plurivora. Rośliny miały około $120 \mathrm{~cm}$ wysokości, dlatego wykluczono możliwość przeniesienia tego gatunku na wierzchołki pędów przez rozpryskiwanie wody $\mathrm{i}$ podłoża $\mathrm{w}$ trakcie podlewania i opadów deszczu. Analiza wody pobieranej do podlewania ze zbiornika usytuowanego na terenie szkółki, wykazała występowanie w nim $P$. citricola $(=P$. plurivora) (Orlikowski 2006). Dalsze obserwacje wykazały stopniowe rozprzestrzenianie się choroby na roślinach, przy czym proces ten przebiegał bardzo szybko (tab. 3).

Orlikowski i wsp. (2010) badali również współzależność pomiędzy źródłem izolatów $P$. citricola $(=P$. plurivora), okresem ich detekcji a chorobotwórczością dla olszy. Izolatami wykrytymi w kanale w szkółce, z rzeki i zbiornika w marcu, maju, lipcu i październiku inokulowano liście olszy i mierzono średnicę nekrotycznych plam (rys. 4). Niezależnie od źródła pochodzenia i terminu detekcji, wszystkie kultury kolonizowały blaszki liściowe. Izolaty uzyskane $\mathrm{z}$ rzeki $\mathrm{z}$ detekcji $\mathrm{w}$ marcu, maju i lipcu zasiedlały tkanki istotnie szybciej niż kultura $\mathrm{z}$ października (rys. 4). Takie współzależności stwierdzono również dla izolatów uzyskanych $\mathrm{z}$ kanału w marcu i lipcu oraz kultury ze zbiornika z miesiąca marca (rys. 4).

Tabela 3. Rozprzestrzenianie się fytoftorozy wierzchołków pędów żywotnika (Thuja occidentalis) w szkółce kontenerowej (Orlikowski 2006)

Table 3. Spread of Phytophthora tip rot of Thuja occidentalis in container - grown nursery (Orlikowski 2006)

\begin{tabular}{c|c|c}
\hline \multirow{2}{*}{$\begin{array}{c}\text { Okres obserwacji } \\
\text { Observation date }\end{array}$} & \multicolumn{2}{|c}{$\begin{array}{c}\text { Liczba porażonych roślin }(\mathrm{n}=200) \text { z symptomami } \\
\text { Number of diseased plants }(\mathrm{n}=200) \text { with symptoms }\end{array}$} \\
\cline { 2 - 3 } & $\begin{array}{c}\text { brązowienie pojedynczych wierzchołków } \\
\text { browning of single tips }\end{array}$ & $\begin{array}{c}\text { brązowienie od 2 do 5 wierzchołków na roślinie } \\
\text { browning of 2-5 tips/plant }\end{array}$ \\
\hline 11.07 .2005 & $10,8 \mathrm{a}$ & $4,3 \mathrm{a}$ \\
\hline 14.07 .2005 & $39,5 \mathrm{~b}$ & $15,3 \mathrm{~b}$ \\
\hline 19.07 .2005 & $55,8 \mathrm{c}$ & $25,0 \mathrm{c}$ \\
\hline
\end{tabular}

Średnie w kolumnach oznaczone tą samą literą, nie różnią się istotnie $(5 \%)$ według testu Duncana

Means in columns followed by the same letter, do not differ according to Duncan's multiple range test 
$\square$ III $\square$ V $\square$ VII $\square \times$ Miesiące - Months

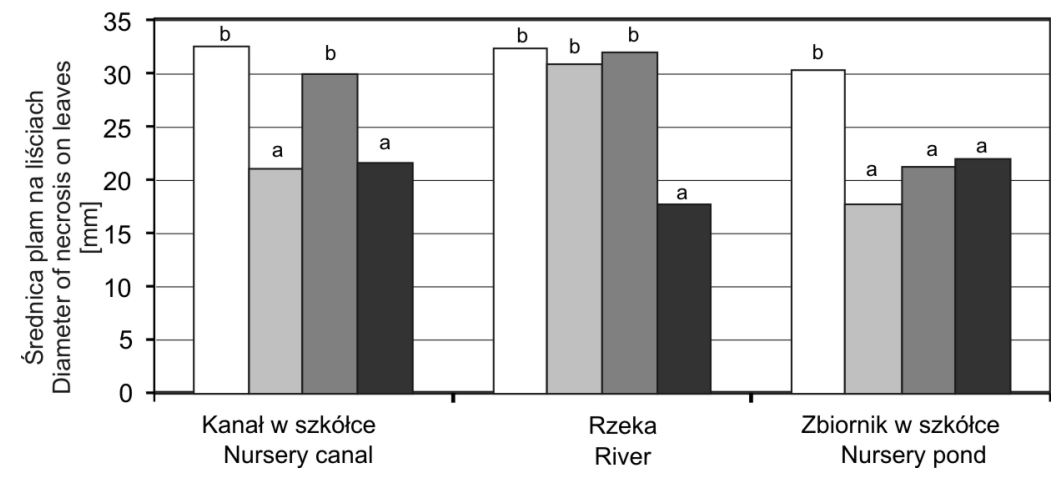

Średnie w kolumnach oznaczone tą sama litera, nie różnią się istotnie (5\%) według testu Duncana Means in columns followed by the same letter, do not differ according to Duncan's multiple range test

Rys. 4. Współzależność pomiędzy źródłem izolatów P. plurivora, okresem ich izolacji a kolonizacją liści olszy (Orlikowski i wsp. 2010) Fig. 4. Relationship between P. plurivora source, detection period and colonisation of alder leaves (Orlikowski et al. 2010)

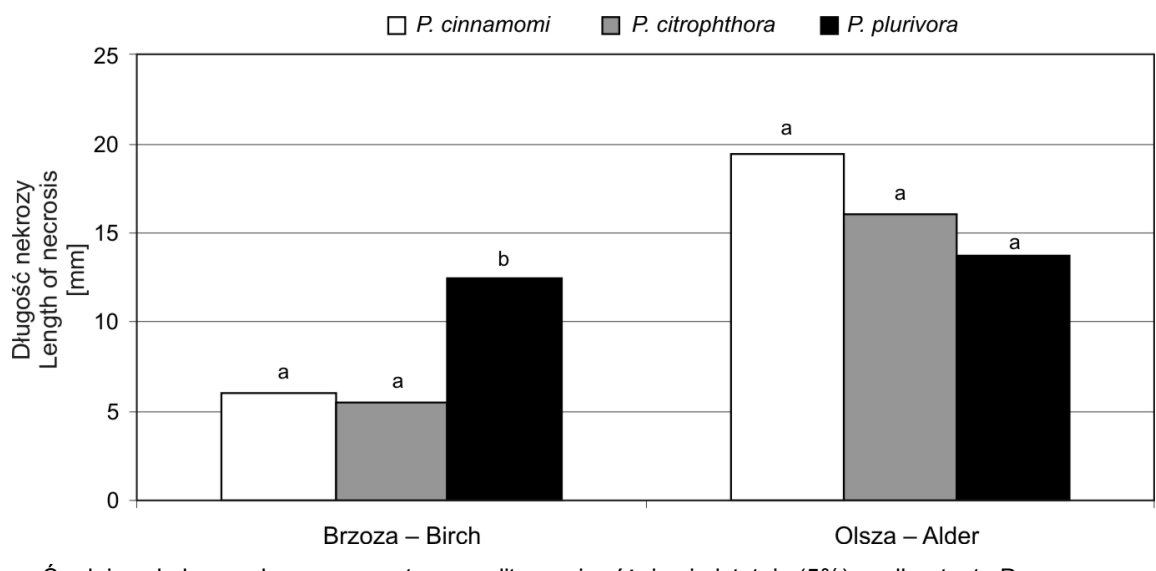

Średnie w kolumnach oznaczone tą samą literą, nie różnią się istotnie (5\%) według testu Duncana Means in columns followed by the same letter, do not differ according to Duncan's multiple range test

Rys. 5. Kolonizacja części łodyg brzozy i olszy przez Phytophthora spp. po 6 dniach od inokulacji (Orlikowski i wsp. 2008)

Fig. 5. Colonisation of birch and common alder stem parts by Phytophthora spp. 6 days after inoculation (Orlikowski et al. 2008)

Badano również kolonizację części łodyg brzozy i olszy przez gatunki $P$. cinnamomi, $P$. citrophthora i $P$. citricola (= P. plurivora) (rys. 5). Tkanki brzozy były kolonizowane $\mathrm{w}$ większym stopniu przez $P$. plurivora niż dwa inne gatunki. Nie stwierdzono natomiast istotnych różnic w długości nekrozy na łodygach olszy (rys. 5).

\section{Wnioski / Conclusions}

1. We wszystkich badanych lokalizacjach i źródłach wody wykrywano gatunki Phytophthora.

2. Stwierdzono występowanie Phytophthora spp. w wodzie przez cały rok, $\mathrm{z}$ dominacją w okresie wiosny i jesieni, co dowodzi, że woda jest powszechnym źródłem bytowania tych patogenów.

3. Dominującym gatunkiem był $P$. plurivora, chociaż często wykrywano również $P$. cambivora, $P$. cinnamomi, P. citrophthora i P. lacustris.
4. Izolaty Phytophthora spp. pochodzące z wody kolonizują tkanki roślin niezależnie od źródła i okresu detekcji.

5. Liście wierzchołkowe różanecznika są najbardziej przydatną w praktyce ogrodniczej i leśnej pułapką do detekcji gatunków Phytophthora.

Opracowanie wykonano w ramach zadania nr 1.8 ,Monitorowanie występowania (Phytophthora spp.), diagnostyka i możliwości ograniczania strat powodowanych przez tę grupę patogenów”, Programu Wieloletniego „Rozwój zrównoważonych metod produkcji ogrodniczej w celu zapewnienia wysokiej jakości biologicznej i odżywczej produktów ogrodniczych oraz zachowania bioróźnorodności środowiska i ochrony jego zasobów", finansowanego przez Ministerstwo Rolnictwa i Rozwoju Wsi.

\section{Literatura / References}

Baker K.F., Matkin O.A. 1978. Detection and control of pathogens in water. Ornamentals Northwest 2 (2): 12-13.

Bewley W.F., Buddin W. 1921. On the fungus flora of glasshouse water supplies in relation to plant diseases. Annals of Applied Biology 8 (1): 10-19. 
Brasier C.M. 2008. The biosecurity threat to the UK and global environment from international trade in plants. Plant Pathology 57 (5): 792-808.

Bush E.A., Hong C.X., Stromberg E.L. 2003. Fluctuations of Phytophthora and Pythium spp. in components of recycling irrigation system. Plant Disease 87 (12): 1500-1506.

Cech Th.L. 2004. Development and spread of the Phytophthora disease of alders in Austria. p. 31. In: Proceedings of the Third International IUFRO Working Party "Phytophthora in forest and natural ecosystems". Germany, Freising, 11-17.09.2004, 167 pp.

Erwin D.C., Ribeiro O.K. 1996. Phytophthora Diseases Worldwide. APS Press, St. Paul, MN, 562 pp.

Gibbs J.N., Lipscombe M.A., Peace A.J. 1999. The impact of Phytophthora disease on riparian popultions of common alder (Alnus glutinosa) in southern Britain. European Journal of Plant Pathology 29 (1): 39-50.

Hansen E., Delatour C. 1999. Phytophthora species in oak forests of north-east France. Annals of Forest Science 56 (7): $539-547$.

Hong C.X., Moorman G.W. 2005. Plant pathogens in irrigation water: challenges and opportunities. Critical Reviews in Plant Sciences 24 (3): 189-208.

Jung T., Blaschke M. 2004. Phytophthora root and collar rot of alders in Bavaria: distribution, modes of spread and possible management strategies. Plant Pathology 53 (2): 197-208.

Kozłowska C., Brennejzen B., Benben K. 1961. Stan zagrożenia lasów polskich w roku 1960 przez ważniejsze choroby pochodzenia grzybowego. Prace Instytutu Badawczego Leśnictwa 226: 47-56.

Matsiakh I., Kramarets V., Orlikowski L.B., Trzewik A. 2012. Pierwsze doniesienie o występowaniu Phytophthora spp. i Pythium litorale w rzekach Beskidu ukraińskich Karpat. [First report of Phytophthora spp. and Pythium litorale occurrence in Beskid's rivers (of the Ukrainian Carpathians)]. Progress in Plant Protection/Postepy w Ochronie Roślin 52 (4): 1200-1203.

Miligroom M.G., Peever T.L. 2003. Population biology of plant pathogens. Plant Disease 87 (6): 608-617.

Murphy S.K., Rizzo D.M. 2003. First report of Phytophthora ramorum on Canyon Live Oak in California. Plant Disease 87 (3), p. 315.

Nechwatal J., Bakonyi J., Cacciola S.O., Cooke D.E.L., Jung T., Nagy Z.A., Vannini A., Vettrraino A.M., Brasier C.M. 2013. The morphology, beheviour, and molecular phylogeny of Phytophthora taxon Salixsoil and its redesignation as Phytophthora lacustris sp. nov. Plant Pathology 62 (2): 355-369.

Nechwatal J., Mendgen K. 2006. Widespread detection of Phytophthora taxon Salixsoil in the littoral zone of Lake Contance, Germany. European Journal of Plant Pathology 114: 261-264.

Orlikowski L.B. 2006. Relationship between source of water used for plant sprinkling and occurrence of Phytophthora shoot rot and tip blight in container-ornamental nurseries. Journal of Plant Protection Research 46 (2): 163-168.

Orlikowski L.B., Gabarkiewicz R., Skrzypczak Cz. 1995. Phytophthora species in Polish ornamental nurseries. I. Isolation and identification of Phytophthora species. Phytopathologia Polonica 21: 73-79.

Orlikowski L.B., Oszako T. 2009. Fytoftorozy w szkółkach i drzewostanach leśnych. Centrum Informacyjne Lasów Państwowych, Warszawa, 67 ss.

Orlikowski L.B., Oszako T., Szkuta G. 2003. First record of alder Phytophthora in Poland. Journal of Plant Protection Research 43 (1): 33-39.

Orlikowski L.B., Ptaszek M. 2009. Rola chwastów ruderalnych i wody w przeżywalności i rozprzestrzenianiu Phytophthora cryptogea w środowisku. [Influence of ruderal plants and water on survival and spread of Phytophthora cryptogea in the environment]. Progress in Plant Protection/Postępy w Ochronie Roślin 49 (3): 1085-1090.

Orlikowski L.B., Ptaszek M., Trzewik A., Orlikowska T. 2008. Współzależność pomiędzy źródłem wody i porą roku a występowaniem Phytophthora spp. w środowisku. [Relationship between source of water, surveying time and occurence of Phytophthora spp.]. Progress in Plant Protection/Postępy w Ochronie Roślin 48 (1): 246-251.

Orlikowski L.B., Ptaszek M., Trzewik A., Orlikowska T. 2011a. Occurrence of Phytophthora species in rivers, canals and water reservoirs in relation to its location. Seasonal analysis and fungicide residues. Ecological Chemistry and Engineering 18 (11): 1551-1556.

Orlikowski L.B., Ptaszek M., Trzewik A., Orlikowska T. 2011b. Przydatność pułapek liściowych do detekcji Phytophthora spp. z wody. Sylwan 155 (7): 493-499.

Orlikowski L.B., Ptaszek M., Trzewik A., Orlikowska T., Wojtkowska M. 2010. Występowanie Phytophthora spp. w wodzie i chorobotwórczość wybranych izolatów P. citricola dla roślin. Zeszyty Problemowe Postępów Nauk Rolniczych 554: 159-164.

Orlikowski L.B., Ptaszek M., Trzewik A., Orlikowska T., Wojtkowska M., Meszka B. 2012a. Woda jako źródło rozprzestrzeniania gatunków Phytophthora w środowisku. Woda - Środowisko - Obszary Wiejskie 12, 3 (39): 179-186.

Orlikowski L.B., Ptaszek M., Trzewik A., Wierzchowski M. 2012b. Występowanie i ocena chorobotwórczości izolatów Phytophthora spp. uzyskanych z rzek i zbiornika wodnego. Sylwan 156 (7): 533-541.

Orlikowski L.B., Szkuta G. 2005. Phytophthora ramorum w Polsce i potencjalne zagrożenie lasów przez ten gatunek. Leśne Prace Badawcze 1: 65-69.

Orlikowski L.B., Wiejacha K. 2005. Phytophthora ramorum - nowy inwazyjny czynnik chorobotwórczy dla roślin na świecie i w Polsce. Postepy Nauk Rolniczych 6: 3-14.

Oszako T., Orlikowski L.B. 2005. Porażone drzewa, siewki olszy i gleba jako źródło Phytophthora alni w Polsce. [Phytophthora alni as the main caus of the alder decline in Poland]. Progress in Plant Protection/Postępy w Ochronie Roślin 45 (1): 343-350.

Oszako T., Orlikowski L.B., Trzewik A., Orlikowska T. 2007. Studies on the occurrence of Phytophthora ramorum in nurseries, forest stands, and garden centers. p. 19-25. In: Monograph "Alien and Invasive Species and International Trade" (H.F. Hugh, T. Oszako, eds). Instytut Badawczy Leśnictwa, Raszyn, 179 pp.

Rizzo D.M., Garbelotto M., Davidson J.M., Slaughter G.W. 2002. Phytophthora ramorum as the cause of extensive mortality of Quercus spp. and Lithocarpus densiflorus in California. Plant Disease 86 (3): 205-214.

Streito J.-C., Legrand P.H., Tabary F., De Villartay J.G. 2002. Phytophthora disease of alder (Alnus glutinosa) in France: investigation between 1995 and 1999. Forest Pathology 32: 17-191.

Themann K., Werres S., Dienner H.-A., Lütmann R. 2002. Comparisson of different methods to detect Phytophthora spp. in recycling water from nurseries. Journal of Plant Pathology 84 (1): 41-50.

Thompson S.V., Allen R.M. 1974. Occurrence of Phytophthora przez species and other potential plant pathogens in recycled irrigation water. Plant Disease Report 58 (10): 945-949. 